\title{
Specialty Cut Flower Production Guidelines for Florida - Zinnia ${ }^{1}$
}

Rick Schoellhorn, Everett Emino, and Erin Alvarez²

\section{General Information}

Zinnia elegans is a composite flower ranging in size from 2 to 6 inches wide on a long stem with opposite lanceolate leaves. With an upright, bushy habit, its size averages 30 inches tall. Dwarf cultivars that grow to 6 inches tall for bedding use are available, and cut flower cultivars up to 3 feet tall are common. Flower types include single, semi-double, double, (dahlia flowered) and cactus (ruffled) flowered. Zinnia is a drought-tolerant, warm-weather annual that does not tolerate frost. This flower is available in a wide variety of colors, and color availability is often seasonally dependent for cut flower sales. Shorter cultivars are also used in annual beds, borders, and containers.

\section{Field Production}

Soil $\mathrm{pH}$ preference 5.5 - 7.5; addition of composted organic matter is beneficial. Research results at UF/IFAS show faster crop time in soils amended with the addition of well-cured compost as well as benefits from enhanced soil properties such as improved cation exchange capacity of the soil.
Zinnia should always be produced in full sun with a minimum daytime temperature of $60^{\circ} \mathrm{F}$. Lower temperatures slow and may halt development. Crop scheduling is highly dependent on temperature, so cold temperatures will have a direct effect on how long it takes to reach flowering size and how many flushes of flowers occur within the season.

Side dress with a commercial fertilizer for row culture. Either supplement fertilized beds with 100 ppm $\mathrm{N}$ in a balanced fertilizer or fertilize with 200 ppm $\mathrm{N}$ in a balanced fertilizer every other watering and at least once a week minimum. The higher the fertilizer levels the faster the crop grows, but avoid fertilizers high in ammonium forms of nitrogen.

Zinnias are grown from seed. Sow seeds directly in the field, or in plug flats. Germination occurs at $74-80^{\circ} \mathrm{F}$ in five to seven days. Plug seedling transplants can be produced; set out 3-6 week old seedlings that have been fertilized weekly prior to transplanting with 20-20-20 at 150ppm. High light is essential to develop quality seedlings. If growing seedlings in plugs, Daminozide can be applied at low rates to tone and control the stretch of seedlings.

1. This document is ENH 953, one of a series of the Environmental Horticulture Department, Florida Cooperative Extension Service, Institute of Food and Agricultural Sciences, University of Florida. Original publication date January 2004. Visit the EDIS Web Site at http://edis.ifas.ufl.edu.

2. Richard Schoellhorn, Associate Professor; Everett Emino, Professor; Erin Alvarez, Student Assistant, Environmental Horticulture Department, Institute of Food and Agricultural Science, University of Florida, Gainesville, FL 32611.

The Institute of Food and Agricultural Sciences (IFAS) is an Equal Employment Opportunity - Affirmative Action Employer authorized to provide research, educational information and other services only to individuals and institutions that function without regard to race, creed, color, religion, age, disability, sex, sexual orientation, marital status, national origin, political opinions or affiliations. For information on obtaining other extension publications, contact your county Cooperative Extension Service office. Florida Cooperative Extension Service / Institute of Food and Agricultural Sciences / University of Florida / Larry R. Arrington, Interim Dean 
Scheduling 60 to 70 days from seed to flower is often cited. However, the time varies considerably depending on the season because of the difference in day length from winter to summer. Sow seeds after last freeze or sow plug seedlings 3 to 4 weeks before the last frost for transplanting. We found that a June sowing took 100 days to first flower while a mid August sowing took 83 days. Sequential planting is important for sustained production of high quality flowers throughout your marketing season.

There is no pinching prior to first flowering for cut flower use. Larger flowers are produced if side shoots are removed. As repeated harvests are made from the crop the length of stems and flower diameter will decrease.

Zinnias are a quantitative short day plant. Longer days lengthen time to flower, but they will flower any time of year. Buds are initiated more quickly during the spring and fall seasons.

Narrow plant spacing is better for flowering, as it reduces side branching, and is best for single harvest; wide spacing at 2 feet between rows and 6 inches within the row is better for multiple harvests. In bed culture, 6 inches between plants was satisfactory for summer production in Florida.

The taller cut flower cultivars often require additional support. Wire or mesh netting is often used when flowers are grown in bed culture. In greenhouse production, a mesh support is routinely used. In field production, select cultivars with strong upright growth habits for best flower quality.

\section{Common Problems}

Bud worms and grasshoppers can damage flowers but can be controlled easily with biological or conventional pesticides. Thrips, alternaria leaf spot, and powdery mildew are often seen. Plants infected with bacterial stem blight should be culled and cut flowers discarded from infected plants. Similarly, virus infected plants should be culled and cutting tools disinfected every few feet of cutting -especially after encountering a virus or bacterial stem blight infected plant. Zinnias are also very sensitive to boron imbalances.

\section{Recommended Cultivars}

'Benarys Giant' series, 'State Fair Mixed' is well known by flower market customers. Smaller flower varieties such as the 'Oklahoma' series or 'Ruffles Mix' produce more salable cut stems per week (4-5) per square foot than the larger varieties like 'Big Red' or 'Benarys Giant' (2), but do not fill up a bouquet as fast. For a more complete listing of commonly grown cultivars see Table 1.

\section{Consumer / Postharvest Information}

Cut Flower: Cut when flowers are fully developed and when pollen begins to show. Leave two to three leaf pairs on each stem. Store cut flowers at $42-45^{\circ} \mathrm{F}$ for up to one week. Zinnias benefit dramatically from the use of floral preservatives in all stages of harvest and postharvest handling. The figure below from UF/IFAS research shows the benefit of extending the vase life with fresh flower food. Do not include flowers in bunches or bouquets that are infected with vascular bacterial stem blight as it will reduce postharvest life drastically.

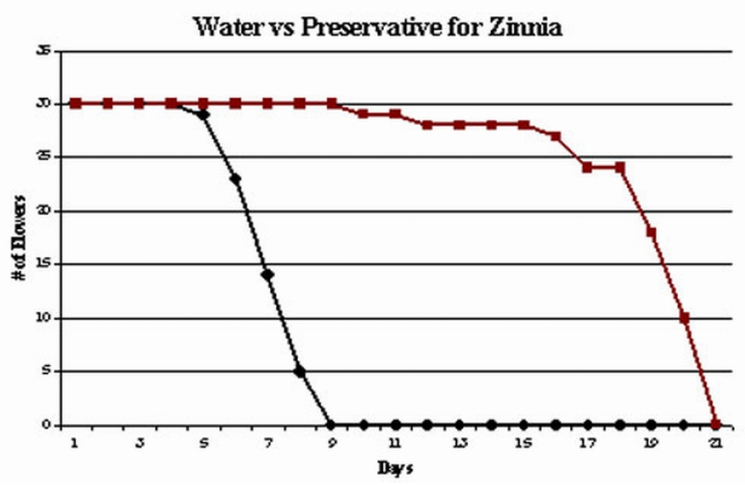

Figure 1. Post harvest characteristics of Zinnia and Sunflower cut flowers as influenced by shipping, hydration and preservatives. Credits: Emino, E. R., and B. Hamilton. 2002. Proceedings of the Florida State Horticultural Society. 115:111-114. 
Table 1. Zinnia cultivars commonly used for outdoor cut flower production.

\begin{tabular}{||l|l|c|c||}
\hline \hline Cultivar & Color & $\begin{array}{c}\text { Plant size } \\
\text { in inches }\end{array}$ & $\begin{array}{c}\text { Flower size } \\
\text { in inches }\end{array}$ \\
\hline Border Beauty & Mixture or rose-toned as a single color. Double blooms. & $18-22$ & $3-4$ \\
\hline Oklahoma & Series of all colors, or mixed blooms. Double blooms & $18-24$ & $3-4$ \\
\hline Marvel Yellow & Yellow. Dahlia type flowers. & 15 & $4-5$ \\
\hline State Fair & Mixture. Double blooms. & $30-36$ & $4-6$ \\
\hline Ruffles Mix & Mixture of colors. Petals ruffled. & $24-30$ & $5-6$ \\
\hline Burpeanna Giant & Mixture. Cactus-flowered. & $30-34$ & $5-6$ \\
\hline Benary Giant & Series of all colors. & $24-30$ & 3 \\
\hline Envy & Chartreuse green. & $30-34$ & $4-6$ \\
\hline Blue Point Series & Full series of colors. & $24-30$ & $3-4$ \\
\hline Pumila & Series of all colors. & 24 & $4-6$ \\
\hline Cactus Flowered Mix & Series of all colors. Petals serrated. & 17 & 3 \\
\hline Candy Cane & Red and white striped flowers. & $24-36$ & $2-2.5$ \\
\hline Cut-N Come Again & Mixture. Singles and doubles. & 30 & $4-5$ \\
\hline Dahlia Flowered Mix & Full series of colors. Petals slightly rolled. & $18-24$ & $2-3$ \\
\hline Lilliput & Full series of colors. Double flowers. & 12 & 3 \\
\hline Rose Pinwheel & Deep rose. Single flowers. & 20 & $3-5$ \\
\hline Whirligig & All double bi-color flowers in assortment. & $3-4 "$ \\
\hline \hline
\end{tabular}

